\title{
Erilaisten kasviöljylisien vaikutus maidon rasvahappokoostumukseen puhtaaseen puna-apilasäilörehuun pohjautuvassa ruokinnassa
}

\author{
Anni Halmemies ${ }^{1,3)}$, Marjo Karasti ${ }^{1)}$, Tuomo Kokkonen ${ }^{1)}$, Seija Jaakkola ${ }^{1)}$, Anna-Maija Lampi ${ }^{2)}$, Vesa \\ Toivonen ${ }^{3)}$, Kevin J. Shingfield ${ }^{3)}$ ja Aila Vanhatalo ${ }^{1)}$ \\ ${ }^{1)}$ HY, Kotieläintieteen laitos, PL 28,00014 Helsingin yliopisto, etunimi.sukunimi@helsinki.fi \\ ${ }^{2)}$ HY, Soveltavan kemian ja mikrobiologian laitos, PL 27, 00014 Helsingin yliopisto, \\ etunimi.sukunimi@helsinki.fi \\ 3) MTT, Kotieläintuotannon tutkimus,31600Jokioinen, etunimi.sukunimi@mtt.fi
}

\section{Tiivistelmä}

Maitorasvan koostumusta voidaan muuttaa ihmisterveydelle suotuisammaksi lehmien ruokintaa muuttamalla. Puna-apilasäilörehun tiedetään lisäävän monityydyttymättömien rasvahappojen, erityisesti $\alpha$-linoleenihapon (18:3n-3), osuutta maitorasvassa. Kasviöljyt ovat heinäkasvi- ja maissisäilörehuun perustuvassa ruokinnassa tyypillisesti vähentäneet maitorasvan tyydyttyneiden ja lisänneet tyydyttymättömien rasvahappojen pitoisuuksia. Rypsiöljy sisältää runsaasti öljyhappoa (18:1n-9), auringonkukkaöljy linolihappoa (18:2n-6) ja camelinaöljy $\alpha$-linoleenihappoa. Camelinapuriste vastaa raakarasva- ja valkuaispitoisuudeltaan rypsipuristetta, mutta sen käytöstä märehtijöiden rehuna on olemassa niukasti tutkimustietoa. Tämän tutkimuksen tarkoituksena oli selvittää maltillisen kasviöljylisäyksen (rypsiöljy, auringonkukkaöljy, camelinaöljy ja camelinapuriste) vaikutus maidon rasvahappokoostumukseen puna-apilaan pohjautuvassa ruokinnassa.

Koe tehtiin Helsingin yliopiston Viikin opetus- ja tutkimustilan navetassa keväällä 2008. Kokeessa oli viisi kaksi kertaa poikinutta ay-lehmää ja se toteutettiin 5 x 5 latinalaisena neliönä. Koejakson pituus oli 21 päivää. Kokeen alkaessa lehmien poikimisesta oli kulunut keskimäärin $115 \pm 5,0$ päivää ja ne lypsivät 33,5 \pm $1,62 \mathrm{~kg}$ maitoa/pv. Koekäsittelyinä olivat väkirehut, jotka kontrollia lukuun ottamatta sisälsivät lipidilisän (29 g/kg väkirehua) rypsiöljystä, auringonkukkaöljystä, camelinaöljystä tai camelinapuristeesta. Lehmät saivat väkirehua $12 \mathrm{~kg} / \mathrm{pv}$ ja apilasäilörehua vapaasti.

Lehmät söivät koko väkirehuannoksensa. Lipidilisä ei vaikuttanut säilörehun syöntiin, maitotuotokseen eikä maidon rasva- tai valkuaispitoisuuteen. Lipidilisä vähensi maitorauhasen de novo -synteesistä peräisin olevien lyhytketjuisten, tyydyttyneiden rasvahappojen pitoisuutta ja lisäsi tyydyttymättömien pitoisuutta maitorasvassa. Rypsiöljyruokinta lisäsi maitorasvan öljyhappopitoisuutta, kun taas linolihappopitoisuus oli suurempi ja $\alpha$-linoleenihappopitoisuus pienempi auringonkukkaruokinnassa camelinaruokintoihin nähden, muutosten heijastaessa lipidilisien rasvahappokoostumusta. Lipidilisä, erityisesti camelinapuriste, lisäsi trans-rasvahappojen osuutta maitorasvassa. Camelinaöljyn antotavalla oli suuri vaikutus maitorasvan koostumukseen. Alfalinoleenihapon pitoisuus oli suurempi annettaessa camelinan lipidit öljynä kuin puristeena. Camelinaöljyn antaminen puristeena lisäsi kaksin-kolminkertaisesti C18-rasvahappojen biohydrogenaation välituotteiden pitoisuuksia maitorasvassa öljyruokintaan verrattuna (trans-10 ja trans-11 18:1, cis-9,trans-11 CLA ja trans-11,cis-15 18:2) ja vähensi steariinihapon (18:0) ja öljyhapon pitoisuuksia. Tämä viittaa rasvahappojen epätäydellisempään tyydyttymiseen pötsissä, kun camelinan lipidit annetaan puristeena eikä öljynä. On mahdollista, että murskattu camelinankuori suojaa siemenen sisällä olevia rasvahappoja pötsin biohydrogenaatiolta ja/tai camelinan siemenessä oleva jokin muu ainesosa inhiboi biohydrogenaatiota.

Asiasanat: lypsylehmä, apilasäilörehu, kasviöljyt, camelina, maitorasva, tyydyttymättömät rasvahapot, CLA, trans-rasvahapot 


\section{Johdanto}

Rasva on tärkeä maidon ainesosa, sillä se vaikuttaa olennaisesti maidon ja maitotuotteiden rakenteeseen, makuun ja säilyvyyteen sekä pehmeyteen suussa. Maidon rasvapitoisuus vaikuttaa myös tuottajahintaan. Maito ja maitotuotteet ovat suomalaisten suurin tyydyttyneiden ja toiseksi suurin trans-rasvahappojen lähde (Hulsof ym. 1999). Kyseisten rasvahappojen runsas saanti lisää riskiä sairastua sepelvaltimo- ja kolesterolitautiin. Toisaalta maitorasva sisältää myös ihmisterveyttä edistäviä rasvahappoja, kuten voihappoa (4:0), haaraketjuisia rasvahappoja, cis-kertatyydyttymättömiä rasvahappoja, konjugoitunutta linolihappoa (CLA) ja $\alpha$-linoleenihappoa (18:3n-3) (Williams 2000; Shingfield ym. 2008).

Maitorasvan koostumusta voidaan muokata muuttamalla lehmien ruokintaa. Puna-apilasäilörehun tiedetään lisäävän monityydyttymättömien rasvahappojen, erityisesti $\alpha$-linoleenihapon, osuutta maitorasvassa heinäkasvisäilörehuun verrattuna (Dewhurst ym. 2003; Vanhatalo ym. 2008). Kasviöljylisät ovat heinäkasvija maissisäilörehuun perustuvissa ruokinnoissa tyypillisesti vähentäneet tyydyttyneiden ja lisänneet steariinihapon (18:0) sekä tyydyttymättömien rasvahappojen, erityisesti öljyhapon (cis-9 18:1), transrasvahappojen, CLA:n ja monityydyttymättömien rasvahappojen pitoisuutta maitorasvassa. Rypsiöljy sisältää runsaasti öljyhappoa, auringonkukkaöljy linolihappoa (18:2n-6) ja camelinaöljy $\alpha$-linoleenihappoa. Öljynpuristuksen sivutuotteena saatava camelinapuriste vastaa raakarasva- ja valkuaispitoisuudeltaan rypsipuristetta, mutta sen käytöstä märehtijöiden rehuna on niukasti tutkimustietoa. Tämän tutkimuksen tarkoituksena oli selvittää maltillisen kasviöljylisäyksen (rypsiöljy, auringonkukkaöljy, camelinaöljy ja camelinapuriste) vaikutus maidon rasvahappokoostumukseen puna-apilaan pohjautuvassa ruokinnassa. Tavoitteena oli asettaa kasviöljylisäys tasolle, jolla maitorasvan koostumus muuttuisi, mutta säilörehun syönti ei vielä vähenisi.

\section{Aineisto ja menetelmät}

Koe tehtiin Helsingin yliopiston Viikin opetus- ja tutkimustilan navetassa keväällä 2008. Kokeessa oli viisi kaksi kertaa poikinutta ay-lehmää ja se toteutettiin 5 x 5 latinalaisena neliönä. Koejakson pituus oli 21 päivää. Kokeen alkaessa lehmien poikimisesta oli kulunut keskimäärin $115 \pm 5,0$ päivää, ne lypsivät 33,5 $1,62 \mathrm{~kg}$ maitoa $/ p v$ ja painoivat $607 \pm 30,3 \mathrm{~kg}$. Koekäsittelyinä olivat väkirehut, jotka kontrollia lukuun ottamatta sisälsivät lipidilisän (29 g/kg väkirehua) rypsiöljystä (RÖ), auringonkukkaöljystä (AÖ), camelinaöljystä (CÖ) tai camelinapuristeesta (CP). Lehmät saivat viljapohjaista väkirehua $12 \mathrm{~kg} / \mathrm{pv}$ neljänä yhtä suurena annoksena klo 6.15, 10.00, 16.45 ja 20.00 sekä puna-apilasäilörehua vapaasti. Punaapilakasvusto (lajike Ilte) oli niitetty 2. sadosta 13.8.2007 ja paalattu pyöröpaaleihin 14. - 15.8.2007. Säilöntäaineena oli muurahaishappopohjainen AIV 2 Plus (6,5 1/t rehua; Kemira Oyj). Paalaus keskeytyi ukkoskuuron vuoksi, mikä vaikutti säilörehun lopulliseen laatuun (Taulukko 1).

Lehmien syönti ja maitotuotos mitattiin päivittäin koko kokeen ajan. Lehmät lypsettiin klo 6.30 ja 17.00. Suhteelliset maitonäytteet maidon valkuais-, rasva- ja ureapitoisuuden sekä rasvahappokoostumuksen määrittämiseksi otettiin jokaisen jakson viimeisellä viikolla neljältä peräkkäiseltä lypsykerralta. Valkuais-, rasva- ja ureapitoisuuden määritystä varten maitonäytteet säilöttiin Bronopol-tableteilla ja näytteet analysoitiin infrapuna-analysaattorilla (Valio, Seinäjoen aluelaboratorio). Rasvahappomääritystä varten maidot $(500 \mathrm{ml})$ pakastettiin $\left(-20^{\circ} \mathrm{C}\right)$ ilman säilöntäainetta.

Rehunäytteet analysoitiin Helsingin yliopiston kotieläintieteen laitoksen laboratoriossa standardimenetelmin. Rasvan uutto, triglyseridien transmetylaatio ja vapaiden rasvahappojen metylaatio rasvahappojen metyyliestereiksi (FAME) rehuista ja maidosta tehtiin Shingfieldin ym. (2003) mukaan MTT

Kotieläintuotannon tutkimuksen laboratoriossa. Rasvahappojen metyyliesterit eroteltiin kaasukromatografissa CP-Sil 88 kapillaarikolonnilla, käyttäen vetyä kantajakaasuna (Shingfield ym. 2003). Rasvahapot tunnistettiin pääasiassa vertaamalla niiden retentioaikoja metyloitujen rasvahappojen standardeihin (GLC 463 ja 606, N-21/23/24-M, U-37/39/43/54/64/85/87-M, Nu-Check-Prep, Elysian, MN; L-8404, H-6389/6639 ja O-4129 Sigma-Aldrich, Helsinki, Finland). Tulosten laskennassa käytettiin teoreettisia vastekertoimia (Wolff ym. 1995).

Konjugoidun linolihapon isomeerit määritettiin nestegromatografilla, jossa oli neljä peräkkäistä ChromSpher Lipids-kolonnia. Ajoliuoksena käytettiin $0.1 \%$ asetonitriiliä (ACN) heptaanissa virtausnopeudella $1 \mathrm{ml} / \mathrm{min}$ (Shingfield ym. 2003). Isomeerit tunnistettiin vertaamalla näytteiden kromatogrammeja metyloitujen CLA-isomeeristandardien kromatogrammeihin (Shingfield ym. 2005).

Tulokset analysoitiin tilastollisesti SAS Mixed -proseduuria käyttäen mallilla, jossa jakso ja ruokinta olivat kiinteinä ja eläin satunnaisena tekijänä. Virhetekijälle jäi mallissa vapausasteita 12. Testattavat ortogonaaliset kontrastit olivat i) lipidilisän vaikutus (kontrolli vs. RÖ, AÖ, CÖ ja CP), ii) kerta- vs. 
monityydyttyneet lipidit (RÖ vs. AÖ, CÖ ja CP), iii) 18:2 vs. 18:3 (AÖ vs. CÖ ja CP) ja iv) lipidilisän antotapa (öljy vs. puriste; CÖ vs. CP).

\section{Tulokset ja tulosten tarkastelu}

Lehmät söivät koko väkirehuannoksensa. Puna-apilasäilörehun keskinkertaisesta säilönnällisestä laadusta huolimatta (Taulukko 1) säilörehun syönti oli hyvä (Taulukko 2). Lipidilisä ei vaikuttanut $(\mathrm{P}>0,05)$ säilörehun syöntiin, maitotuotokseen eikä maidon rasva- tai valkuaispitoisuuteen.

Maidon rasvahappokoostumus on esitetty taulukoissa 2-4. Maitorasvan $\alpha$-linoleenihappopitoisuus oli suhteellisen suuri kaikilla koeruokinnoilla verrattuna aikaisempiin rypsi-, auringonkukka- ja camelinakokeisiin (Dewhurst ym. 2006; Hurtaud ja Peyraud 2007; Glasser ym. 2008), johtuen todennäköisesti punaapilapohjaisesta ruokinnasta (Dewhurst ym. 2003, Vanhatalo ym. 2007). Lipidilisä vähensi maitorauhasen de novo -synteesistä peräisin olevien lyhytketjuisten, tyydyttyneiden rasvahappojen pitoisuutta ja lisäsi tyydyttymättömien pitoisuutta maitorasvassa. Maitorasvan C4-14 ja palmitiinihappo(16:0)-pitoisuudet vähenivät keskimäärin 2,6 ja 5,5 \%-yksikköä, vastaavasti lipidilisän myötä. Pitkäketjuisten rasvahappojen saanti oli huomattavasti suurempi lipidiruokinnoissa ja niiden tiedetään vähentävän tyydyttyneiden rasvahappojen synteesiä maitorauhasessa (Barber ym. 1997). Lipidilisä lisäsi steariinihapon, cis-12/15 18:1:n ja trans-rasvahappojen, erityisesti trans-18:1 -rasvahappojen, pitoisuutta maitorasvassa. Kyseisiä rasvahappoja muodostuu pötsissä, kun rehun tyydyttymättömät C18-rasvahapot biohydrogenoituvat. Biohydrogenaatiossa tyydyttymättömät rasvahapot pelkistyvät, kun kaksoissidoksiin liittyy vetyä $\left(\mathrm{H}_{2}\right)$. Rehun linoli- ja $\alpha$-linoleenihaposta keskimäärin jopa $87 \%$ biohydrogenoituu pötsissä (Glasser ym. 2008). Monityydyttymättömät rasvahapot olisivat suurina määrinä myrkyllisiä etenkin kuitua sulattaville bakteereille (Maia ym. 2007).

Maitorasvan öljyhappopitoisuus lisääntyi keskimäärin 3,1 \%-yksikköä lipidilisän myötä. Steariinija/tai öljyhapon virtaus pötsistä on todennäköisesti ollut suurempi lipidiruokinnoissa kontrolliin verrattuna. Lisäksi merkittävä osa steariinihaposta desaturoituu maitorauhasessa öljyhapoksi (Chilliard ym. 2000). Maitorasvan cis-9,trans-11 CLA-pitoisuus lisääntyi keskimäärin 0,3 \%-yksikköä lipidilisän myötä. Rehun monityydyttymättömien rasvahappojen biohydrogenaation seurauksena maitorauhasessa osittain cis-9, trans11 CLA:ksi desaturoituvan trans-11 18:1:n (Griinari ja Bauman 1999) saatavuus on todennäköisesti ollut maitorauhasessa suurempi lipidiruokinnoissa. Cis-9,trans-11 CLA on myös yksi linolihapon biohydrogenaation päävälituotteista (Harfoot ja Hazlewood 1998). Lipidiruokinta vähensi tai sillä ei ollut vaikutusta parittomien ja haaraketjuisten rasvahappojen pitoisuuksiin maitorasvassa, mikä viittaa vähäisiin muutoksiin pötsin mikrobipopulaatiossa. Maitorasvan paritonhiiliset ja haaraketjuiset rasvahapot ovat peräisin pötsimikrobien rasvahapposynteesistä (Vlaeminck ym. 2006).

Rypsiöljyruokinta lisäsi maitorasvan öljyhappopitoisuutta, kun taas linolihappopitoisuus oli suurempi ja $\alpha$-linoleenihappopitoisuus pienempi auringonkukkaruokinnalla camelinaruokintoihin nähden, muutosten heijastaessa lipidilisien omaa rasvahappokoostumusta. Auringonkukkaöljy lisäsi camelinaan verrattuna linolihapon biohydrogenaation välituotteiden, trans-8,trans-10 ja trans-10,trans-12 CLA:n (Chilliard ym. 2007; Shingfield ym., 2008b) pitoisuutta maitorasvassa. Maitorasvan cis/trans-12,cis-15 ja trans11,cis/trans-15 18:2:n sekä cis/trans-11,trans-13 CLA:n pitoisuudet olivat suuremmat camelinaruokinnoissa auringonkukkaruokintaan verrattuna. Collomb ym. (2004) sekä Rego ym. (2009) ovat havainneet samankaltaisia muutoksia maitorasva 18:2-koostumuksessa verratessaan linolihappo- ja $\alpha$-linoleenihappolisiä toisiinsa. Maitorasvan $\alpha$-linoleenihappo- sekä cis/trans-15 18:1-pitoisuus oli suurempi camelinakuin auringonkukkaruokinnassa, heijastaen $\alpha$-linoleenihapon pienempää saantia auringonkukkaruokinnassa, sillä cis/trans-15 18:1 muodostuu pötsissä $\alpha$-linoleenihapon biohydrogenoituessa (Harfoot ja Hazlewood 1988; Chilliard ym. 2007; Doreau ym. 2009). Camelinaöljy sisältää huomattavia määriä cis-11 20:1 (taulukko 1), mikä selittää C20-rasvahappojen suurempaa pitoisuutta maitorasvassa syötettäessä camelinaa kuin auringonkukkaöljyä.

Camelinaöljyn antotavalla oli suuri vaikutus maitorasvan koostumukseen. Alfalinoleenihapon pitoisuus oli suurempi annettaessa camelinan lipidit öljynä kuin puristeena. Camelinaöljyn antaminen puristeena lisäsi kaksin-kolminkertaisesti C18-rasvahappojen biohydrogenaation välituotteiden pitoisuuksia maitorasvassa (trans-10 ja trans-11 18:1, cis-9,trans-11 ja trans-11,cis-15 18:2) ja vähensi steariinihapon ja öljyhapon pitoisuuksia, mikä viittaa epätäydellisempään rasvahappojen tyydyttymiseen pötsissä. Mihhejev ym. (2007) sekä Hurtaud ja Peyraud (2007) ovat saaneet samansuuntaisia tuloksia maissi- ja heinäkasvisäilörehuun perustuvilla ruokinnoilla. On mahdollista, että murskattu camelinankuori suojaa 
siemenen sisällä olevia rasvahappoja pötsin biohydrogenaatiolta tai että camelinan siemenessä oleva jokin muu ainesosa inhiboi biohydrogenaatiota.

\section{Johtopäätökset}

Maltillinen kasviöljylisä (240 g rasvahappoja/pv) puna-apilasäilörehupohjaisessa ruokinnassa muutti maidon rasvahappokoostumusta vähentämällä toivotusti tyydyttyneiden, lähinnä 12:0, 14:0 ja 16:0, rasvahappojen pitoisuutta maidossa ja lisäämällä kerta- ja monityydyttymättömien rasvahappojen pitoisuutta. Kasviöljylisä ei vaikuttanut säilörehun syöntiin tai maitotuotokseen. Rasvalisät muovasivat suuresti maitorasvan C18rasvahappokoostumusta. Rypsiöljy lisäsi maitorasvan öljyhappopitoisuutta, auringonkukkaöljy linolihappopitoisuutta, camelinaöljy $\alpha$-linoleenihappopitoisuutta ja camelinapuriste cis-9,trans-11 CLA:ta, muutosten heijastaessa rasvalisien rasvahappokoostumusta. Camelinan antaminen puristeena lisäsi huomattavasti maitorasvan tyydyttymättömien rasvahappojen, etenkin trans-rasvahappojen ja CLA:n, pitoisuutta vastaavaan öljylisään verrattuna. Murskattu camelinankuori saattaa suojata siemenen sisällä olevia rasvahappoja pötsin biohydrogenaatiolta ja/tai camelinan siemenessä oleva jokin muu ainesosa inhiboi rasvahappojen biohydrogenaatiota pötsissä.

\section{Kirjallisuus}

Barber, M.C., Clegg, R.A., Travers, M.T. \& Vernon, R.G. 1997. Lipid metabolism in the lactating mammary gland. Biochem. Biophy. Acta 1347:101-126.

Chilliard,Y., Ferlay, A., Mansbridge, R.M. \& Doreau, M. 2000. Ruminant milk fat plasticity: nutritional control of saturated, polyunsaturated, trans and conjugated acids. Ann. Zootech. 49:181-205.

Chilliard, Y., Glasser, F., Ferlay, A., Bernard, L., Ruel, J. \& Doreau, M. 2007. Diet, rumen biohydrogenation and nutritional quality of cow and goat milk. Eur. J. Lipid Sci. Technol. 109:826-855.

Collomb, M., Sieber, R. and Bütikofer, U. 2004. CLA isomers in milk fat from cows fed diets with high levels of unsaturated fatty acids. Lipids 39:355-364.

Dewhurst, R.J., Fisher, W.J., Tweed, J.K.S. \& Wilkins, R.J. 2003. Comparison of grass and legume silages for milk production. 1. Production responses with different levels of concentrate. J. Dairy Sci. 86:2598-2611.

Dewhurst, R.J., Shingfield, K.J., Lee, M.R.F. \& Scollan, N.D. 2006. Increasing the concentrations of beneficial fatty acids in milk produced by dairy cows in high-forage systems. Anim. Feed Sci. Technol. 131:168-206.

Doreau, M., Laverroux, S., Normand, J., Chesneau, G. and Glasser, F. 2009. Effect of linseed fed as seeds, extruded seeds or oil on fatty acid rumen metabolism and intestinal digestibility in cows. Lipids 44:53-62.

Glasser, F., Schmidely, P., Sauvant, D.\& Doreau, M. 2008b. Digestion of fatty acids in ruminants: a meta-analysis of flows and variation factors: 2. C18 fatty acids. Anim. 2:691-704.

Griinari, J.M. \& Bauman, D.E. 1999. Biosynthesis of Conjugated Linoleic Acid and Its Incorporation into Meat and Milk in Ruminants. Teoksessa: Advances in Conjugated Linoleic Acid Research. Vol. 1. M.P. Yurawech, M.M. Mossoba, J.K.G. Kramer, M.W. Pariza, and G.J. Nelson, (toim.). AOCS Press. Champaign, Illinois. ss 180-200.

Harfoot, C.G. \& Hazlewood, G.P. 1988. Lipid metabolism in the rumen. Teoksessa: The Rumen Microbial Ecosystem. P.N. Hobson (toim.). Elsevier Applied Sci. Publ., London, United Kingdom. ss 285-322.

Hulsof, K.F.A.M., Van Erp-Baart, M.A., Anttolainen, M., Becker, W., Church, S.M., Couet, C., Hermann-Kunz, E., Kesteloot, H., Leth, T., Martins, I., Moreiras, O., Moschandreas, J., Pizzoferrato, L., Rimestad, A.H., Thorgeirsdottir, H., Van Amelsvoort, J.M.M., Aro, A., Kafatos, A.G., Lanzmann-Petithory, D. \& Van Poppel, G. 1999. Intake of fatty acids in Western Europe with emphasis on trans fatty acids. The TRANSFAIR study. European Journal of Clinical Nutrition 53: 147-157.

Hurtaud, C. \& Peyraud, J. L. 2007. Effects of feeding Camelina (seeds or meal) on milk fatty acid composition and butter spreadability. J. Dairy Sci. 90:5134-5145.

Maia, M.R.G., Chaudhary, L.C., Figueres, L., \& Wallace, R.J. 2007. Metabolism of polyunsaturated fatty acids and their toxicity to the microflora of the rumen. Ant. Leeuw. 91:303-314.

Mihhejev, K., Henno, M., Ots, M., Rihma, E., Elias, P., Kuusik, S. \& Kärt, O. 2007. Effects of fat-rich oil cakes on cheese fatty acid composition, and on cheese quality. Vet. Zootech. 40:55-61.

Rego, O.A., Alves, S.P., Antunes, L.M.S., Rosa, H.J.D., Alfaia, C.F.M., Prates, J. A.M., Cabrita, A.R.J., Fonseca, A.J.M. \& Bessa, R.J.B. 2009. Rumen biohydrogenation-derived fatty acids in milk fat from grazing dairy cows supplemented with rapeseed, sunflower, or linseed oils. J. Dairy Sci. 92:4530-4540.

Shingfield, K.J., Ahvenjärvi, S., Toivonen, V., Ärölä, A., Nurmela, K.V.V., Huhtanen, P. \& Griinari, J.M. 2003. Effect of dietary fish oil on biohydrogenation of fatty acids and milk fatty acid content in cows. Anim.Sci. 77:165-179.

Shingfield, K.J., Reynolds, C.K., Lupoli, B., Toivonen, V., Yurawecz, M.P., Delmonte, P., Griinari, J.M., Grandison, A.S. \& Beever, D.E. 2005. Effect of forage type and proportion of concentrate in the diet on milk fatty acid composition in cows given sunflower oil and fish oil. Anim. Sci. 80:225-238. 
Shingfield, K.J., Ahvenjärvi, S., Toivonen, V., Vanhatalo, A., Huhtanen, P. \& Griinari, J.M. 2008a. Effect of incremental levels of sunflower-seed oil in the diet on ruminal lipid metabolism in lactating cows. Br. J. Nutr. 99:971-983.

Shingfield, K.J., Chilliard, Y., Toivonen, V., Kairenius, P. and Givens, D.I.. 2008b. Trans fatty acids and bioactive lipids in ruminant milk. Teoksessa: Bioactive components of milk, Advances in Experimental Medicine and Biology. Vol. 606. Z. Bösze, (toim.). Springer, New York, NY. ss 3-65.

Vanhatalo, A., Kuoppala, K., Toivonen, V. \& Shingfield, K.J. 2007. Effects of forage species and stage of maturity on bovine milk fatty acid composition. Eur. J. Lipid Sci. Technol. 109:856-867.

Vlaeminck, B., Fievez, V., Cabrita, A.R.J., Fonseca, A.J.M. \& Dewhurst, R.J. 2006. Factors affecting odd- and branched-chain fatty acids in milk: a review. Anim. Feed Sci. Technol. 131:389-417.

Williams, C.M. 2000. Dietary fatty acids and human health. Ann. Zootech. 49:165-180.

Wolff, R.L., Bayard, C.C. \& Fabien, R.J. 1995. Evaluation of sequential methods for the determination of butterfat fatty acid composition with emphasis on trans-18:1 acids. Application to the study of seasonal variations in french butters. Journal of the American Oil Chemists' Society 72:1471-1483.

\section{Kiitokset}

Tämä tutkimus on osa Omegamaitoa puna-apilasta ja camelinasta -hanketta. Tutkimusta ovat tukeneet Tekes, Valio Oy, Rehuraisio Oy ja Kemira Oyj.

Taulukko 1. Koerehujen kemiallinen koostumus.

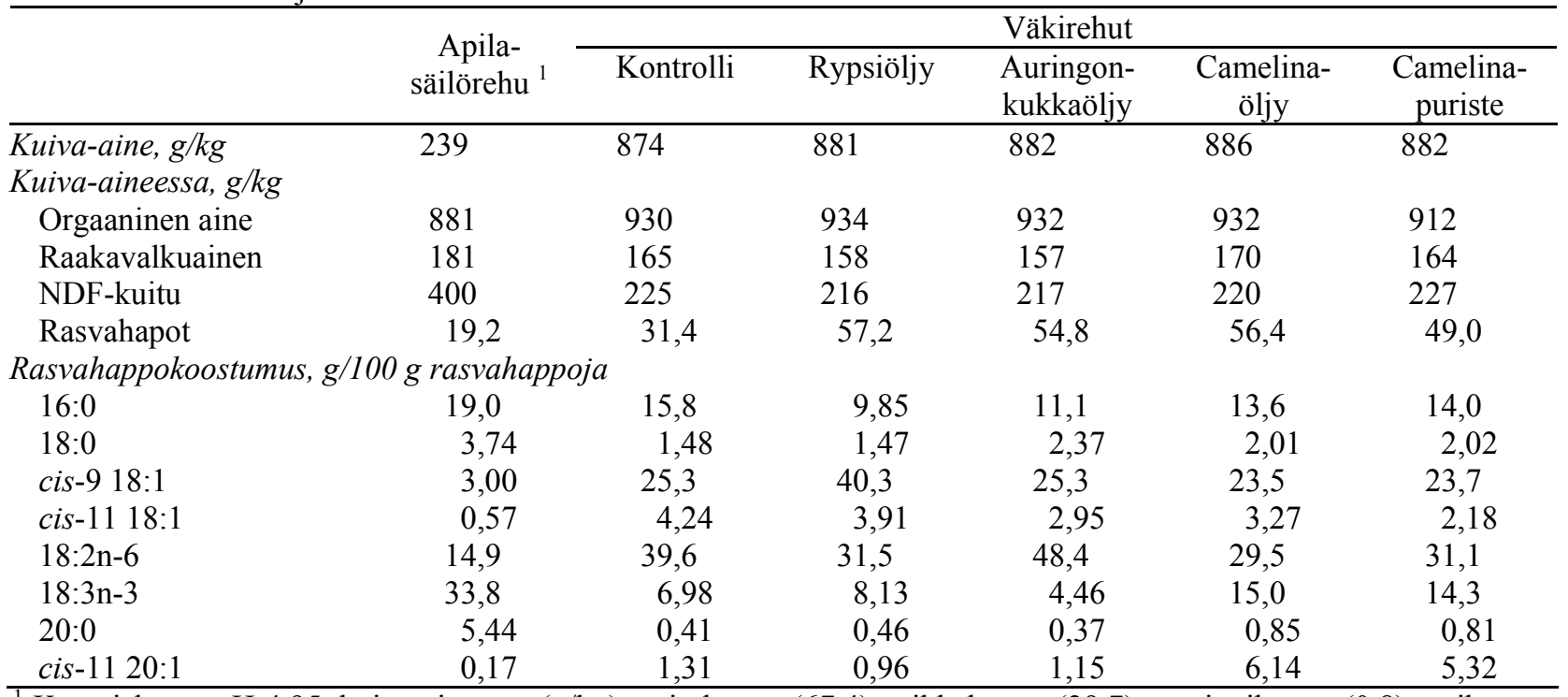

${ }^{1}$ Käymislaatu: $\mathrm{pH} 4,95$, kuiva-aineessa $(\mathrm{g} / \mathrm{kg})$ maitohappo $(67,4)$, etikkahappo $(29,7)$ propionihappo $(0,8)$, voihappo $(7,6)$, kokonaistypestä $(\mathrm{g} / \mathrm{kg})$ ammoniumtyppi $(161)$, in vitro OA:n sulavuus $63,4 \%$ 
Taulukko 2. Kasviöljyjen ja camelinapuristeen vaikutus syöntiin, maitotuotokseen ja maidon koostumukseen punaapilapohjaisessa ruokinnassa.

\begin{tabular}{|c|c|c|c|c|c|c|c|c|c|}
\hline \multicolumn{5}{|c|}{ Dieetti $^{1}$} & \multirow{3}{*}{ SEM } & \multicolumn{4}{|c|}{ Tilastollinen merkitsevyys ${ }^{2}$} \\
\hline & & & & & & & MUFA & $18: 2$ & Öljy \\
\hline Kontrolli & RÖ & AÖ & $\mathrm{CÖ}$ & $\mathrm{CP}$ & & Lipidit & $\begin{array}{c}\text { vs. } \\
\text { PUFA }\end{array}$ & $\begin{array}{c}\text { vs. } \\
18: 3 \\
\end{array}$ & $\begin{array}{c}\text { vs. } \\
\text { puriste }\end{array}$ \\
\hline
\end{tabular}

\begin{tabular}{|c|c|c|c|c|c|c|c|c|c|c|}
\hline \multicolumn{11}{|l|}{$\overline{\text { Syönti,kg/d }}$} \\
\hline Säilorehu ka & 12,9 & 12,8 & 12,4 & 12,7 & 12,2 & 0,44 & & & & $\circ$ \\
\hline Dieetti ka & 23,3 & 23,4 & 23,0 & 23,3 & 22,7 & 0,46 & & & & $\circ$ \\
\hline \multicolumn{11}{|l|}{ Saanti, $g / d$} \\
\hline cis-9 18:1 & 95,4 & 256 & 161 & 153 & 134 & 1,38 & $* * *$ & $* * *$ & $* * *$ & $* * *$ \\
\hline $18: 2 n-6$ & 177 & 233 & 330 & 221 & 204 & 1,8 & $* * *$ & $* * *$ & $* * *$ & $* * *$ \\
\hline $18: 3 n-3$ & 114 & 138 & 113 & 181 & 161 & 3,3 & $* * *$ & $* * *$ & $* * *$ & $* * *$ \\
\hline$\Sigma$ Rasvahapot & 609 & 876 & 857 & 877 & 782 & 11,1 & $* * *$ & $* * *$ & $* *$ & $* * *$ \\
\hline \multicolumn{11}{|l|}{ Tuotos } \\
\hline Maito, kg/d & 31,1 & 32,3 & 32,3 & 31,2 & 32,2 & 2,65 & & & & \\
\hline EKM, kg/d & 30,5 & 31,3 & 30,6 & 30,5 & 30,4 & 2,63 & & & & \\
\hline Rasva, g/d & 1225 & 1255 & 1178 & 1234 & 1192 & 117,5 & & & & \\
\hline Valkuainen, g/d & 1013 & 1027 & 1050 & 992 & 1014 & 71,6 & & & $\circ$ & \\
\hline \multicolumn{11}{|l|}{ Pitoisuus maidossa } \\
\hline Rasva, g/kg & 39,6 & 38,6 & 36,4 & 39,3 & 36,7 & 1,70 & & & & \\
\hline Valkuainen, $\mathrm{g} / \mathrm{kg}$ & 33,0 & 32,0 & 32,6 & 32,3 & 31,5 & 0,90 & $\circ$ & & & \\
\hline Urea, mg/100 ml & 40,6 & 36,5 & 36,6 & 38,1 & 34,2 & 2,20 & $\circ$ & & & \\
\hline \multicolumn{11}{|c|}{ Maitorasvan koostumus g/100 g rasvahappoja } \\
\hline $4: 0$ & 3,35 & 3,54 & 3,58 & 3,57 & 3,67 & 0,085 & $* *$ & & & \\
\hline $6: 0$ & 1,76 & 1,72 & 1,71 & 1,69 & 1,69 & 0,034 & $*$ & & & \\
\hline $8: 0$ & 1,23 & 1,14 & 1,14 & 1,14 & 1,09 & 0,044 & $* * *$ & & $\circ$ & $*$ \\
\hline 10:0 & 3,19 & 2,75 & 2,76 & 2,72 & 2,57 & 0,169 & $* * *$ & & $\circ$ & $\circ$ \\
\hline $12: 0$ & 3,91 & 3,24 & 3,24 & 3,20 & 3,08 & 0,214 & $* * *$ & & & \\
\hline $14: 0$ & 13,0 & 11,8 & 11,7 & 11,6 & 11,9 & 0,29 & $* * *$ & & & $*$ \\
\hline$\sum \mathrm{C} 15$ & 2,22 & 2,01 & 1,98 & 1,92 & 1,98 & 0,077 & $* * *$ & $*$ & & $\circ$ \\
\hline $16: 0$ & 32,4 & 27,3 & 26,5 & 27,1 & 26,8 & 1,38 & $* * *$ & & & \\
\hline$\sum$ cis $16: 1$ & 1,60 & 1,38 & 1,34 & 1,36 & 1,52 & 0,032 & $* * *$ & & $\circ$ & $* *$ \\
\hline $\bar{\sum}$ trans $16: 1$ & 0,29 & 0,31 & 0,28 & 0,31 & 0,41 & 0,020 & $* * *$ & $* *$ & $* * *$ & $* * *$ \\
\hline$\sum 16: 1$ & 1,89 & 1,68 & 1,62 & 1,67 & 1,93 & 0,032 & $* * *$ & & $* * *$ & $* * *$ \\
\hline $\bar{\Sigma} \mathrm{C} 17$ & 1,21 & 1,11 & 1,12 & 1,11 & 1,23 & 0,042 & $* *$ & $*$ & $*$ & $* *$ \\
\hline $18: 0$ & 7,63 & 10,4 & 10,9 & 9,86 & 7,33 & 0,468 & $* * *$ & $* * *$ & $* * *$ & $* * *$ \\
\hline$\sum$ cis $18: 1$ & 14,5 & 18,7 & 18,1 & 18,1 & 15,7 & 0,62 & $* * *$ & $* *$ & $* *$ & $* * *$ \\
\hline$\sum$ trans $18: 1$ & 4,02 & 5,20 & 5,55 & 4,91 & 8,28 & 0,267 & $* * *$ & $* *$ & $* *$ & $* * *$ \\
\hline$\sum 18: 1$ & 18,5 & 23,9 & 23,7 & 23,0 & 24,0 & 0,72 & $* * *$ & & & $*$ \\
\hline$\sum 18: 2^{3}$ & 2,96 & 2,97 & 3,50 & 3,23 & 4,14 & 0,128 & $* * *$ & $* * *$ & $* *$ & $* * *$ \\
\hline$\sum \mathrm{CLA}^{4}$ & 0,59 & 0,77 & 0,83 & 0,79 & 1,33 & 0,052 & $* * *$ & $* * *$ & $* * *$ & $* * *$ \\
\hline $18: 3 n-3$ & 1,10 & 1,02 & 0,99 & 1,17 & 1,06 & 0,049 & & $\circ$ & $* *$ & $* *$ \\
\hline $20: 0$ & 0,42 & 0,40 & 0,41 & 0,77 & 0,57 & 0,036 & $* * *$ & $* * *$ & $* * *$ & $* * *$ \\
\hline cis-9 20:1 & 0,33 & 0,30 & 0,29 & 0,58 & 0,49 & 0,023 & $* * *$ & $* * *$ & $* * *$ & $* * *$ \\
\hline$\sum$ cis $20: 1$ & 0,50 & 0,45 & 0,45 & 1,24 & 1,20 & 0,052 & $* * *$ & $* * *$ & $* * *$ & \\
\hline$\sum$ trans $20: 1$ & 0,08 & 0,07 & 0,07 & 0,23 & 0,29 & 0,015 & $* * *$ & $* * *$ & $* * *$ & $*$ \\
\hline$\sum 20: 1$ & 0,58 & 0,52 & 0,53 & 1,47 & 1,49 & 0,065 & $* * *$ & $* * *$ & $* * *$ & \\
\hline \multicolumn{11}{|l|}{ Yhteenveto } \\
\hline$\sum C 4-C 14$ & 28,6 & 26,2 & 26,0 & 25,9 & 25,8 & 0,65 & $* * *$ & & & \\
\hline$\sum$ Trans-rasvahapot & 5,98 & 7,43 & 7,77 & 7,45 & 12,4 & 0,375 & $* * *$ & $* * *$ & $* * *$ & $* * *$ \\
\hline$\sum$ Tyydyttyneet & 71,0 & 66,1 & 65,9 & 65,4 & 62,6 & 1,01 & $* * *$ & $* *$ & $* * *$ & $* * *$ \\
\hline $\bar{\sum}$ Kertatyydyttymättömät & 23,2 & 28,1 & 27,7 & 28,2 & 29,7 & 0,78 & $* * *$ & & $* *$ & $* *$ \\
\hline$\sum$ Monityydyttymättömät & 5,33 & 5,40 & 5,99 & 5,93 & 7,27 & 0,240 & $* * *$ & $* * *$ & $* * *$ & $* * *$ \\
\hline
\end{tabular}

${ }^{1}$ Viittaa puna-apilasäilörehupohjaisiin ruokintoihin: rasvalisätön kontrolli, rypsiöljy (RÖ), auringonkukkaöljy (ÄÖ), camelinaöljy (CÖ) ja camelinapuriste (CP).

${ }^{2}$ Ortogonaaliset kontrastit i) lipidilisän vaikutus (lipidit; kontrolli vs. RÖ, AÖ, CÖ ja CP), ii) kerta- vs. monityydyttyneet lipidit (MUFA vs. PUFA; RÖ vs. AÖ, CÖ ja CP), iii) 18:2 vs. 18:3 (AÖ vs. CÖ ja CP) ja iv) lipidilisän antotapa (öljy vs. puriste; $\mathrm{CÖ}$ vs. $\mathrm{CP}$ ). ${ }^{*} \mathrm{P}<0,05,{ }^{*} \mathrm{P}<0,01$, ${ }^{*} * * \mathrm{P}<0,001$, o $\mathrm{P}<0,10$, jos tyhjä $\mathrm{P}>0,10$.

${ }^{3}$ Energiakorjattu maitotuotos; ${ }^{4} \mathrm{Ilman}$ konjugoitua linolihappoa; ${ }^{5} \mathrm{Konjugoitu}$ linolihappo 
Taulukko 3. Kasviöljyjen ja camelinapuristeen vaikutus maitorasvan paritonhiilisten ja haaraketjuisten rasvahappojen koostumukseen (mg/100g rasvahappoja) puna-apilapohjaisessa ruokinnassa.

\begin{tabular}{|c|c|c|c|c|c|c|c|c|c|c|}
\hline & \multicolumn{5}{|c|}{ Dieetti $^{1}$} & \multirow[b]{2}{*}{ SEM } & \multicolumn{4}{|c|}{ Tilastollinen merkitsevyys ${ }^{2}$} \\
\hline & Kontrolli & RÖ & AÖ & CÖ & $\mathrm{CP}$ & & Lipidit & $\begin{array}{c}\text { MUFA } \\
\text { VS. } \\
\text { PUFA }\end{array}$ & $\begin{array}{c}18: 2 \\
\text { Vs. } \\
18: 3 \\
\end{array}$ & $\begin{array}{l}\text { Öljy } \\
\text { vs. } \\
\text { puriste }\end{array}$ \\
\hline 13:0 iso & 23,2 & 21,2 & 20,7 & 20,0 & 21,8 & 1,47 & $*$ & & & \\
\hline 13:0 anteiso & 7,86 & 7,34 & 7,22 & 6,67 & 6,97 & 0,400 & $*$ & & & \\
\hline $14: 0$ iso & 117 & 113 & 107 & 106 & 109 & 5,5 & $\circ$ & & & \\
\hline $15: 0$ & 1368 & 1233 & 1191 & 1688 & 1206 & 31,6 & $* * *$ & $* *$ & & $\circ$ \\
\hline $15: 0$ iso & 185 & 165 & 162 & 158 & 159 & 8,3 & $* * *$ & & & \\
\hline 15:0 anteiso & 479 & 434 & 441 & 423 & 433 & 40,1 & $* * *$ & & & \\
\hline $16: 0$ iso & 266 & 238 & 269 & 242 & 265 & 17,4 & & & & \\
\hline $17: 0$ & 649 & 585 & 603 & 583 & 582 & 18,9 & $* * *$ & & $* *$ & \\
\hline $17: 0$ iso $^{3}$ & 285 & 276 & 285 & 281 & 366 & 16,7 & & $* *$ & $* *$ & $* * *$ \\
\hline
\end{tabular}

${ }^{1}$ Viittaa puna-apilasäilörehupohjaisiin ruokintoihin: rasvalisätön kontrolli, rypsiöljy (RÖ), auringonkukkaöljy (ÄÖ), camelinaöljy (CÖ) ja camelinapuriste (CP).

${ }^{2}$ Ortogonaaliset kontrastit i) lipidilisän vaikutus (lipidit; kontrolli vs. RÖ, AÖ, CÖ ja CP), ii) kerta- vs. monityydyttyneet lipidit (MUFA vs. PUFA; RÖ vs. AÖ, CÖ ja CP), iii) 18:2 vs. 18:3 (AÖ vs. CÖ ja CP) ja iv) lipidilisän antotapa (öljy vs. puriste; $\mathrm{CÖ}$ vs. $\mathrm{CP}$ ). ${ }^{*} \mathrm{P}<0,05$, ** $\mathrm{P}<0,01$, *** $\mathrm{P}<0,001$, o $\mathrm{P}<0,10$, jos tyhjä $\mathrm{P}>0,10$.

${ }^{3}$ Mukana trans-9 16:1

Taulukko 4. Kasviöljyjen ja camelinapuristeen vaikutus maitorasvan 18:1- ja 18:2-koostumukseen puna-apilapohjaisessa ruokinnassa.

\begin{tabular}{|c|c|c|c|c|c|c|c|c|c|c|}
\hline & \multicolumn{5}{|c|}{ Dieetti $^{1}$} & \multirow[b]{2}{*}{ SEM } & \multicolumn{4}{|c|}{ Tilastollinen merkitsevyys $^{2}$} \\
\hline & Kontrolli & RÖ & AÖ & CÖ & $\mathrm{CP}$ & & Lipidit & $\begin{array}{c}\text { MUFA } \\
\text { vs. } \\
\text { PUFA }\end{array}$ & $\begin{array}{c}18: 2 \\
\text { VS. } \\
18: 3\end{array}$ & $\begin{array}{c}\text { Öljy } \\
\text { vs. } \\
\text { puriste }\end{array}$ \\
\hline \multicolumn{11}{|c|}{ 18:1 koostumus, g/100g rasvahappoja } \\
\hline $18: \ln -9$ & 13,2 & 17,3 & 16,6 & 16,5 & 13,5 & 0,59 & $* * *$ & $* * *$ & $* * *$ & $* * *$ \\
\hline cis-12 18:1 & 0,33 & 0,38 & 0,57 & 0,46 & 0,85 & 0,047 & $* * *$ & $* * *$ & $\circ$ & $* * *$ \\
\hline cis-15 $18: 1^{3}$ & 0,24 & 0,23 & 0,21 & 0,27 & 0,64 & 0,021 & $* * *$ & $* * *$ & $* * *$ & $* * *$ \\
\hline trans-10 18:1 & 0,36 & 0,51 & 0,56 & 0,42 & 0,96 & 0,045 & $* * *$ & $* *$ & $*$ & $* * *$ \\
\hline trans-11 18:1 & 0,96 & 1,28 & 1,42 & 1,21 & 2,18 & 0,082 & $* * *$ & $* * *$ & $* *$ & $* * *$ \\
\hline trans-15 18:1 & 0,48 & 0,53 & 0,53 & 0,57 & 0,79 & 0,024 & $* * *$ & $* * *$ & $* * *$ & $* * *$ \\
\hline \multicolumn{11}{|c|}{ Ei-konjugoitu 18:2 koostumus, mg/100g rasvahappoja } \\
\hline cis-9, cis-12 18:2 & 2084 & 1985 & 2547 & 2095 & 1978 & 91,5 & & $* *$ & $* * *$ & \\
\hline cis-12, cis-15 18:2 & 28,8 & 35,5 & 30,1 & 61,4 & 53,5 & 2,89 & $* * *$ & $* * *$ & $* * *$ & $*$ \\
\hline trans-11, cis-15 18:2 & 153 & 161 & 109 & 226 & 618 & 24,0 & $* * *$ & $* * *$ & $* * *$ & $* * *$ \\
\hline trans -12, cis-15 18:2 & 70,7 & 69,7 & 62,8 & 82,7 & 128 & 3,5 & $* * *$ & $* * *$ & $* * *$ & $* * *$ \\
\hline trans -11, trans -15 18:2 & 34,3 & 39,2 & 36,9 & 49,6 & 102 & 4,19 & $* * *$ & $* * *$ & $* * *$ & $* * *$ \\
\hline \multicolumn{11}{|c|}{ Konjugoitu 18:2 koostumus, mg/100g rasvahappoja } \\
\hline cis-9, trans-11 CLA & 441 & 560 & 636 & 567 & 1020 & 43,9 & $* * *$ & $* * *$ & $* * *$ & $* * *$ \\
\hline cis-11, trans-13 CLA & 1,58 & 1,28 & 1,33 & 2,20 & 2,79 & 0,196 & & $* *$ & $* * *$ & $*$ \\
\hline trans -8, trans -10 CLA & 3,09 & 3,81 & 6,28 & 3,99 & 4,31 & 0,275 & $* * *$ & $* * *$ & $* * *$ & $\circ$ \\
\hline trans -10, trans -12 CLA & 4,27 & 6,18 & 11,87 & 6,68 & 9,34 & 0,617 & $* * *$ & $* * *$ & $* * *$ & $* * *$ \\
\hline trans-11, trans-13 CLA & 18,1 & 23,8 & 19,7 & 36,1 & 51,3 & 2,80 & $* * *$ & $* * *$ & $* * *$ & $* * *$ \\
\hline
\end{tabular}

${ }^{1}$ Viittaa puna-apilasäilörehupohjaisiin ruokintoihin: rasvalisätön kontrolli, rypsiöljy (RÖ), auringonkukkaöljy (ÄÖ), camelinaöljy (CÖ) ja camelinapuriste (CP).

${ }^{2}$ Ortogonaaliset kontrastit i) lipidilisän vaikutus (lipidit; kontrolli vs. RÖ, AÖ, CÖ ja CP), ii) kerta- vs. monityydyttyneet lipidit (MUFA vs. PUFA; RÖ vs. AÖ, CÖ ja CP), iii) 18:2 vs. 18:3 (AÖ vs. CÖ ja CP) ja iv) lipidilisän antotapa (öljy vs. puriste; $\mathrm{CÖ}$ vs. $\mathrm{CP}$ ). ${ }^{*} \mathrm{P}<0,05, * * \mathrm{P}<0,01, * * * \mathrm{P}<0,001$, o $\mathrm{P}<0,10$, jos tyhjä $\mathrm{P}>0,10$.

${ }^{3}$ Mukana 19:0

${ }^{4}$ Mukana cis-11 19:1 